\title{
On the Need for Integrated System and Cooperation for Preventing and Combating Domestic Violence (Estonia's experience)
}

\author{
Lecturer Silvia Kaugia \\ Department of Criminal Justice \\ University of Tartu \\ Näituse 20, Tartu 50409, Estonia \\ PhD Iris Pettai \\ Estonian Institute for Open Society Research \\ Näituse 20, Tartu 50409, Estonia \\ Professor Raul Narits \\ Department of Public Law \\ University of Tartu \\ Näituse 20, Tartu 50409, Estonia
}

\begin{abstract}
The article addresses, based on studies carried out in Estonia, cooperation between specialists in preventing and combating domestic violence in Estonia. The corresponding expert surveys were carried out by the Estonian Institute for Open Society Research in 2014-2015 and 2017, which make it possible to analyze the efficiency of the existing system in preventing domestic violence and which joins the police, prosecutors, judges, social workers, general practitioners etc. The article further analyses the aspects of juridical regulation of domestic violence in Estonia, including the necessity for drafting a domestic violence prevention act as a precondition for creating a system necessary for the specialists' cooperation. Another goal was to study cooperation between institutions and specialists in combating domestic violence and the causes of its frequent inadequacy. The article also analyses how the positions and values as well as attitude towards domestic violence have changed among the population and specialists between 2001 and 2015 and 2017.
\end{abstract}

Keywords: preventing domestic violence; combating domestic violence; sociology of law, criminal law, criminal policy; criminal procedure

\section{Introduction}

A total of 2,997 domestic violence crimes were registered in Estonia in 2015, ten percent more than in 2014 and 55 percent more than in 2011. Domestic violence amounted to approximately ten percent of all crimes and 38 percent of violent crimes in 2015. (Crime in Estonia, 2015). In 2016, 3,017 domestic violence crimes were registered, 20 more than in 2015. (Crime in Estonia, 2016). Starting from 2011 the share of domestic violence crimes of total and violent crimes has been steadily increasing.(Crime in Estonia, 2015). In 2015, 42 percent of women in Estonia in the age between 15 and 74 had experienced violence since their 15th year of age until the moment of interview. (Pettai, Proos and Laidmäe, 2016). This figure concentrates the cases of mental, physical and sexual violence experienced by women after childhood. Forty percent of men since their 15th year until the interview had also experienced violence, but violence against men at home only amounts to one fifth of the cases, while 80 percent occur outside home.

It is significant that president of the Republic of Estonia Kersti Kaljulaid addressed domestic violence in her speech on the $99^{\text {th }}$ anniversary of the republic: "The police know - people are beaten up the most frequently during holidays. It happens in the place which should be the safest of all - at home. This happens during Christmas and on Midsummer Day. This happens today on the anniversary of the republic." (Kaljulaid, 2017)

Domestic violence is not a problem to be addressed only when the number of violent domestic crimes should statistically increase. This is a central problem the solving of which calls for cooperation between various organizations and institutions, including collaboration considering their interests and purposes.

Estonia lacks a separate law for the prevention of domestic violence and combating it. We have made a number of proposals in juridical publications calling for the drafting of such integrated legal solution - a corresponding law. (Pettai, Kaugia and Narits, 2015a; Pettai, Narits and Kaugia, 2015b; Narits, Kaugia and Pettai, 2016). 
The more developed a society is and the more are there various institutions and cooperation between them, the more efficient can be the prevention of domestic violence and combating the manifestations of domestic violence. Therefore, considering the situation in Estonia, the development of an integrated juridical solution should include, more vigorously than previously, regulative norms besides the law enforcement norms, so as to direct various institutions towards cooperation and coordination of their activities.

The final report of the project "Developing a joint system for the prevention of intimate partner violence in Estonia" recommends proceeding from the "Guidelines for development of legislative policy until 2018" in movement towards a domestic violence act. We hope that a corresponding decision on policymaking will be made, since increasing political resoluteness is the prime requirement of good legislative practice. Further progress should involve the intent to develop a bill on intimate partnership violence (describing the problem, setting the objective, describing possible solutions of the problem, judging the compatibility of the solutions with the national legal system, presenting comparative analysis of the solution with countries with social structure and legal system similar to Estonia, submit the description of the planned regulation).

\section{On the opinions and positions of Estonia's practicing legal experts concerning the prevention of and combating domestic violence}

This article is based on the nationwide expert survey of legal practitioners within the framework of the 2014 project "Developing a joint system for the prevention of intimate partnership violence in Estonia" supported by the Norwegian financial mechanism and the Estonian Ministry of Social Affairs and the follow-up survey carried out in 2017. Since the level of domestic violence is high in Estonia and the solutions hitherto used for preventing and combating violence have proved insufficient, the purpose of the surveys was defined as follows:

a) to determine the preparedness and ability of legal specialists to prevent and combat domestic violence and to cooperate with other institutions;

b) to decide what to do in the present situation and what can legal specialists do within the limits of the existing legal acts. (Pettai, 2015).

At this juncture it seems inevitable to discuss the essence of domestic violence. This is also a key issue concerning the drafting and approval of a law on domestic violence. If domestic violence is treated as a typical act of violence (as the current Estonian legal system does), one could wonder why is this phenomenon so much discussed and written about wouldn't it be sufficient to observe the statistics and dynamics of violent crimes. Within the limits of the nature of domestic violence arises the issue of its connection with violence against women.

The extent and consequences of violence differ according to the type of violence and the victim's gender. For example, in case of registered instances of domestic violence a large share of the victims are women - every eighth victim out of ten. In cases of domestic violence, sexual violence and human trafficking the violence suffered by women is often more serious and the consequences more severe. Therefore it is necessary to pay attention to violence against women in the strategy for the prevention of violence. (Strategy for prevention ..., 2015). For the above reason the question in our study concerning the severity of domestic violence was worded in a way which would enable learning the respondents' opinion of violence against women as a problem.

It is certainly necessary to keep in mind while analyzing the results of the expert interviews below that the legal specialists interviewed judged domestic violence based not on their personal views, but attempted to create a link between the binding legal framework serving as the basis of their professional activities and the efficiency of solving problems. It is also highly positive that the respondents do not underestimate violence against women, but consider it a serious problem in case of all types of violence.

According to either study, mental and physical violence are considered greater problem than sexual abuse. However, the follow-up survey (2017) shows that according to the respondents, all the above forms of violence are rather serious problems; on the other hand, the opinion that it is a very serious problem has declined regarding all forms of violence. In the opinion of respondents to either survey, the most serious problem is mental violence, which is considered a rather serious problem by $37-42 \%$ in the 2014 survey and 54-55\% in the 2017 survey. The following problem as to severity is physical violence, judged as rather serious problem by $52-53 \%$ in the 2014 study and by $50-61 \%$ in the follow-up survey. A significant shift has occurred in the assessment of sexual violence: while it was considered rather serious by $32-33 \%$ in 2014 , the share was $33-39 \%$ in 2017 . On the other hand it is remarkable that the follow-up study reveals an increase of the number of respondents, who do not consider physical or sexual violence a serious problem. A common feature of both studies is the fact that a significant percentage of the respondents expresses no opinion regarding the seriousness of various forms of violence and the follow-up study reveals a growing tendency: 
while $8 \%$ of legal experts has no position regarding the seriousness of mental violence in 2014, their share had increased to $12 \%$ in the 2017 study; this percentage regarding physical violence is respectively 7 and 12; the share of experts not having an opinion regarding sexual violence has somewhat declined - both among lawyers and police detectives. While we previously cited the positive fact that the share of law enforcement personnel considering sexual violence a rather serious problem has increased, it is also noteworthy that the tendency not to consider sexual violence a serious problem is growing (2\% of lawyers in 2014, 7\% in 2017; 7\% of police personnel in 2014 and $11 \%$ in 2017). The cause of this tendency could be the fact that legal practitioners encounter such incidents less frequently and that sexual violence is a less obvious form of violence which the specialists are not adequately aware of.

As was mentioned above, only a few laws in Estonia address domestic violence issues. There is no specific law on domestic violence in Estonia.

We used the expert studies to learn how practicing legal specialists rate the opportunities provided by existing laws for handling domestic violence cases and whether a special domestic violence act would improve the efficiency of handling domestic violence cases in Estonia in the respondents' opinion. The comparison of the two surveys shows a decline (from $15 \%$ to $10 \%$ ) of those believing that the current legal framework provides for adequate handling of domestic violence, while the number of those stating that it generally does not enable adequate handling has declined as well (from 22 to 16\%). Predominant share of respondents states in both surveys that the existing legal framework generally allows for adequate handling of domestic violence. The number of respondents unable to answer has increased significantly (from $4 \%$ to $12 \%$ ).

Estonia has no separate law on domestic violence and this may be one of the reasons why we are mainly concentrating on dealing with the consequences of violence rather than preventing it. We studied in the survey the need for a law on domestic violence.

The respondents can be divided into supporters and sceptics regarding their attitude towards the need for a special law on domestic violence. The share of supporters among lawyers increased in the period 2014-2017 from 34\% to $46 \%$ and declined among police detectives from 52\% to 37\%. The share of sceptics has declined among lawyers from 57\% to $42 \%$ and among police detectives from $40 \%$ to $36 \%$. Only every tenth lawyer and $2 \%$ of police detectives oppose the idea of a special law.

A number of countries have successfully implemented laws on domestic violence and have achieved remarkable results. While the law against domestic violence existed only in one country in 1976, such laws have been passed in 140 countries by now. We asked the respondents to judge the statements used as a basis for recommending the introduction of a special law on domestic violence. (UN Woman, 2018)

The survey displays the respondents' support to all arguments favoring the law on domestic violence. The primary argument is the organization of cooperation between institutions, supported by $77-86 \%$ respondents; ensuring preemptive action and prevention of serious incidents is also viewed as highly important - it is backed by $68-84 \%$. Two thirds of respondents emphasize considering the repetitive nature of domestic violence and underlining the specific features of domestic violence by the law.

Lawyers are somewhat more supportive of different arguments than police detectives. The survey allows us to argue that the anticipation for the law on domestic violence is notably high among Estonia's practicing legal specialists. Legal practitioners perceive numerous bottlenecks and unsolved problems in the existing legal regulation and practice, which the law on domestic violence would hopefully overcome.

Based on the UH data there are currently 119 countries in the world, where the law on domestic violence has been approved.(UN Woman, 2018). In the opinion of the authors of the article, a law on domestic violence would efficiently contribute to the coordination of cooperation between various institutions and to the prevention of domestic violence; introducing it in Estonia is worth serious consideration. (Pettai, Kaugia and Narits, 2015a; Pettai, Narits and Kaugia, 2015b; Narits, Kaugia and Pettai, 2016).

The key issue in ensuring the victims' safety and preventing and combating violence is the capability of the state in handling the cases of domestic violence. There are several parameters for judging it and the questionnaire of the expert survey included the most significant.

The capability of the state is judged differently. The respondents are the most satisfied with the treatment of the victims by law enforcement institutions as well as ensuring the security of the victims' children. Yet the respondents claim that several key problems go unsolved.The greatest satisfaction, according to both surveys, concerns the treatment of victims by law enforcement agencies, while the ensuring of security of the victims' children is also satisfactory. The results of the follow-up survey show an increase (from $2 \%$ to $4 \%$ ) among respondents believing that the state can more efficiently combat domestic violence and prevent serious cases. 
Nevertheless, respondents to both surveys find that the state is still facing considerable problems organizing this activity: it was seen as unsatisfactory by $65 \%$ of respondents in 2014 and by $46 \%$ in 2017. Respondents also criticize the state for lacking control over perpetrators of violence (73\% in 2014; 56\% in 2017) and over the situation in violent households (70\% in 2014, 68\% in 2017). According to the experts, the state displays its complete inefficiency in providing the victims with subsistence and other material resources for independent existence: it is judged as inadequate $79 \%$ of respondents in the 2014 survey and by $61 \%$ in the 2017 survey.

It can be concluded from the experts' responses that the capability of the state is lower in the aspects related to the prevention of domestic violence and higher in handling the consequences of domestic violence.

Only every fourth domestic violence case reported to the police ever reaches the court in Estonia; i.e. $25 \%$ of cases. Only $13 \%$ of cases in turn result in actual prison sentence. (Salla \& Surva, 2012). The main reason of this situation is, in the opinion of $40-65 \%$ of respondents to the expert survey, the victims' withdrawal of their initial testimony. Another important cause, according to $28-57 \%$ of respondents, is the difficulty of proving violence cases. Other possible causes, for example, superficial manner of gathering evidence or secondary importance of domestic violence cases, are not viewed as significant. The lowest number of respondents agrees with the argument that domestic violence cases do not qualify as crime.

We also attempted to find out with the survey the possible reasons for the victims' withdrawal of their initial testimony. According to the respondents, victims withdraw their charges under the influence of the violent party as well as because the victims change their mind on their own. Surprisingly, an increasing number of police investigators believe that the recommendations of acquaintances, friends and relatives of the victim significantly contribute to the withdrawal of charges. This attitude is probably related to the attitude of blaming the victim, which is widely spreadin the society.

The study shows that the stereotypical and prejudicial attitudes of blaming the victim have become established and are stable, no significant changes have been observed in the period 2014-2017. The most supported attitude was the one concerning irresponsible women, who hitch-hike, get drunk, go along with strangers and seemingly provoke violence by their own recklessness and stupidity. A predominant share of respondents, 67-71\%, supported this view. The second quite widespread idea of blaming the women states that women nag their men until the latter lose their self-control and become violent. This position was supported by $60-76 \%$ of respondents. The third statement - women become victims of sexual violence primarily due to their provocative behavior and dress - found significantly less support among the experts: only $24 \%$ of prosecutors, $40 \%$ of judges and $42 \%$ of police investigators agreed with it.

We also asked the respondents to judge two typical attitudes blaming the violent male. They considered the most significant causes of using violence the men's inability to manage their aggressiveness (lack of anger management skills) and excessive need for control - these positions were supported by 88-98\% of respondents.

It can be stated, proceeding from the survey, that Estonia needs programs addressing violent individuals (of both genders), (mandatory) psychological counseling, anger management training etc.

Most of the district police officers in Estonia (86\%-94\%) are constantly handling cases of domestic violence. The scope of frequently used activities is wide: informing social workers and child welfare workers, directing victims to victim support workers, monitoring households with reported domestic violence cases, meeting with perpetrators, influencing them, etc. District officers quite frequently recommend the victims to approach other institutions providing support to victims - medics, psychologists and family counselors. Such measures are frequently used by $51 \%-69 \%$ of respondents; $96 \%$ of district police officers provide legal advice to victims. Juvenile officers are also active in handling domestic violence cases, $87 \%-90 \%$ of them forward information about incidents to social and child welfare workers, recommend the victims to approach victim support. Juvenile officers use monitoring, meeting with perpetrators and legal counseling less frequently than district police officers. (Pettai \& Proos, 2015).

Nearly all police personnel participating in the survey (92\%) as well as a predominant part of prosecutors $(86 \%)$ and judges $(77 \%)$ are dealing with domestic violence cases in their daily work. Yet the share of working time spent in handling domestic violence cases is significantly smaller: an average $42 \%$ in case of police officers, $33 \%$ on case of prosecutors and only $12 \%$ in case of judges. Every fourth judge does not handle domestic violence cases at all, while $41 \%$ dedicate to them minimum amount (up to $5 \%$ ) of working time.

The situation where practicing legal specialists cannot fully concentrate on domestic violence cases can be explained with their high work load in handling different cases. A practical solution to it could be special police investigators, departments of the prosecutor's office and courts staffed with specialists trained for handling domestic violence cases. The expert survey showed that the Estonian law enforcement institutions could use a specialized structural unit handling cases of domestic violence. 
The comparison of the two studies shows that a majority of the respondents support the establishment of a specialized structural unit in the law enforcement agencies for handling domestic violence cases. The responses to the options "definitely necessary" and "probably necessary" break down as follows according to the groups: prosecutors in 2017 66\% (in 2014-48\%); judges in $2017-70 \%$ (in $2014-68 \%$ ); police investigators in $2017-85 \%$ (in $2014-68 \%$ ); lawyers in $2017-82 \%$. Such results correlate with the positions of the respondents that domestic violence is a serious problem in the society and demonstrate the need for handling it by personnel specializing in this sphere. We also asked in the survey, which other specialists should be involved in this structure besides legal experts. Ninety-five percent of all respondents considered a psychologist necessary, $88 \%$ a social worker and $34 \%$ a pedagogue.

Since there is currently no such specialized unit in Estonia's law enforcement institutions, the issue of practicing legal specialists' continuous and advanced education becomes even more important. The results of the survey of experts show that improving their knowledge of domestic violence and additional training are important for them and that all specialists' significantly high need for advanced training is a general tendency.

The responses show that the perceived need for additional training has somewhat changed among the respondents between the two studies: while according to the 2014 study the judges perceived the greatest need for additional training (72\% of respondents), in 2017 the share of this response was the highest among the prosecutors (74\%) while the judges perceived the least need for training (50\% of respondents). The police investigators are the only group of specialists who highly valued the need for additional training according to either study: in $2014-68 \%$, in $2017-71 \%$. Police investigators also included, in comparison with the others, the lowest share of those unable to rate the need for additional training. Answers to the two latter questions testify about the legal practitioners' need for closer cooperation with other specialists.

\section{Institutional and competence-based cooperation in preventing and combating domestic violence in Estonia}

An integrated system and cooperation are the key issues in preventing and combating domestic violence. Every institution and specialist should have a clearly determined role and tasks in the prevention of violence, timely intervening and keeping serious cases from occurring. A peculiarity of the cases of domestic violence is that many specialists from different institutions and departments encounter these problems - from patrols to detectives within the police. District officers will further cooperate with social workers and children's protection specialists of the local governments. At the local level the school psychologists and social pedagogues join them. Further there are law enforcement specialists, prosecutors, judges and attorneys. Domestic violence victims are often encountered by victim support workers and staff of women' shelters. Then there are health care workers in the emergency medical services, general practitioners and gynecologists.

The prosecutor's office and the judicial system play an important role. The prosecutor's office runs the pre-trial judicial procedure, ensuring its legality and efficiency; it represents the state indictment at court, takes part in the planning of investigative activities necessary for the prevention and solving of crimes and performs other tasks the prosecutor's office is charged with by the law. The prosecutor's office as the leading agency of the criminal process directs the investigating agencies in the gathering of evidence and according to the established circumstances decides whether a suspect should be indicted. The mission of the court is to protect the rights of the citizens and legal interests in accordance with the laws of the Republic of Estonia. (The Ministry of Justice, 2017). The present system for preventing and combating domestic violence was set up approximately 10-12 years ago in a situation, where incidents of domestic violence were reported to the police 3-4 times every day. Since the number of cases is presently more than ten times higher, the existing system needs to be analyzed and developed further.

Determining the level of cooperation between specialists in preventing and combating domestic violence is based on the expert surveys of 2014-2015 (Pettai \& Proos, 2014; Pettai \& Kase, 2014; Pettai \& Proos, 2015), organized by the Estonian Institute for Open Society Research, which helped to analyze the efficiency of the present system combining the police, prosecutors, judges, social workers, general practitioners etc. in the prevention of domestic violence and supporting victims. Another goal was assessing cooperation with other institutions and specialists on domestic violence and the reasons of frequently insufficient cooperation. We analyze the legal practitioners' ratings of cooperation with all partners (see Table 1 for cooperation between different specialists).

\section{Cooperation with prosecutors and police investigators}

The comparison of the two studies shows that the highest average rating of the specialists participating in the study concerns cooperation with prosecutors and police investigators. The rating of cooperation with prosecutors has declined since the previous study from $56 \%$ to $49 \%$, while the rating of cooperation with police investigators has remained unchanged: $49 \%$ of respondents rate it as good according to either study. Thus prosecutors and police investigators are definitely vitally important specialists for all practicing legal experts handling cases of domestic violence. 


\section{Cooperation with victim support workers}

According to average ratings, victim support workers came third. The comparison of the two studies shows that cooperation of the respondents with the staff of victims' aid organizations has improved somewhat: it was rated as good in 2014 by $36 \%$ of all respondents, in 2017 the average share of respondents of this opinion was $41 \%$.

\section{Cooperation with judges}

Judges came fourth in the ranking of average ratings, but the specialists' opinion of cooperation with judges has declined between the two studies: while in $201433 \%$ of all respondents considered cooperation with judges good, according to the 2017 study, only $26 \%$ of respondents rated it as good. The more modest position is primarily caused by the judges' own lower rating of cooperation with their colleagues (32\% of judges rated cooperation as good in 2014 and $25 \%$ in 2017) compared with prosecutors and police investigators.

\section{Cooperation with local governments' child welfare workers}

According to the results of the 2017 study, cooperation with municipal children's welfare officials occupies the fifth position in the scale of average rankings: cooperation with them was rated as good by $19 \%$ of all respondents in 2014 and by $21 \%$ in 2017.The ratings of police investigators are the highest: $27 \%$ rated cooperation as good in the 2014 study and 30\% in the 2017 study. There were no respondents among police investigators who would have considered cooperation with child welfare services unimportant. Prosecutors' ratings of cooperation with child welfare specialists were the most critical: 14\% of prosecutors rated cooperation as good in 2014 and $16 \%$ in 2017.

\section{Cooperation with women's shelter staff}

The staff of women's shelters ranked sixth. According to both studies, $20 \%$ of respondents considered cooperation with shelters good. Judges were the most critical about cooperation with women's shelters: while in $20148 \%$ of judges considered cooperation with the shelters' staff good, the share was 5\% according to the 2017 study. Cooperation of prosecutors and police investigators has improved, according to the study: it was rated as good by $26 \%$ of prosecutors in the 2017 study (in $2014-21 \%$ ) and by 36\% (in 2014-29\%) of police investigators.

\section{Cooperation with local governments' social workers}

Local governments' social workers hold the seventh position and are the first party of the network, whose cooperation is rated as inadequate rather than good by practicing legal experts. Positive ratings (good cooperation) of partners in the first six positions outweighed negative ratings (inadequate cooperation). In the comparison of the two studies the specialists' rating of cooperation with municipal social workers has declined: in 2014 an average 14\% of practicing legal experts rated cooperation with municipal social workers as good, while in 2017 it was $10 \%$.

\section{Cooperation with staff of local school}

The specialists' average rating of cooperation with the local school staff has remained the same in the comparison of the two studies $-9 \%$. It is remarkable that all specialists rate cooperation as better when compared with the previous period of study: $8 \%$ of prosecutors (in $2014-5 \%$ ), $5 \%$ of judges (in $2014-4 \%$ ) and $21 \%$ if police investigators (in $2014-18 \%$ ) consider their cooperation with local school staff as good.

\section{Cooperation with family counselors and psychologists}

Legal experts' ratings of cooperation with family counsellors and psychologists are have deteriorated between the 2014 and 2017 studies: an average $13 \%$ of respondents considered cooperation as good in 2014 and 8\% in 2017. Out of all respondents prosecutors rated their cooperation as improving - it was described as good by 16\% (in 2014 - 14\%). Among police investigators cooperation is rated as good by 5\% (in $2014-17 \%$ ) and among judges 0\% (in 2014 $12 \%$ ) of respondents.

\section{Cooperation with representatives of women's organizations}

An average 4\% (in 2014 - 5\%) of respondents consider their cooperation good. According to both studies 5\% of respondents among prosecutors rate their cooperation with women's organizations as good, the rating among police investigators is $7 \%$ (in $2014-8 \%$ ) and among judges $0 \%$ (in $2014-8 \%$ ).

\section{Cooperation with general practitioners and specialist physicians}

Legal experts are the most critical about cooperation with medics compared with all other groups of specialists rated in the survey. Critical attitude towards cooperation is also affected by the fact that many legal practitioners have no experience of cooperating with medics. According to the 2017 study, only an average $3 \%$ of respondents (in $2014-$ $6 \%$ ) consider their cooperation with medics good. The share of whose reporting improved cooperation is the highest among prosecutors $-8 \%$ (in $2014-5 \%$ ); none of the judges rated their cooperation with medics as good in 2017 (in $2014-4 \%$ ), out of police investigators $2 \%$ gave positive rating (in $2014-10 \%$ ). 
It can be concluded that prosecutors cooperate on cases of domestic violence significantly more actively than judges. However, the prosecutors' scope of cooperation is relatively limited. Prosecutors are quite actively cooperating with police investigators, victims' aid workers and judges. They have practically no cooperation with general practitioners and other health care specialists, social workers, women's shelters, school pedagogues, psychologists and family counselors.

Judges are significantly less involved in cooperation with other specialists concerning domestic violence. They cooperate to some extent with prosecutors and other judges, but have not developed closer contacts with other specialists.

Prosecutors and judges play an important role in handling domestic violence cases. Most prosecutors (86\%) and judges (77\%) encounter cases of domestic violence in their daily work, while the related workload amounts to one third of the prosecutors' total working time and only $12 \%$ of that of the judges. Limited cooperation with other specialists is definitely complicating the work of prosecutors and especially judges; there is less background information, opportunities for in-depth analysis of cases, gathering of additional evidence etc. The situation could be solved by establishing a separate structural unit in the law enforcement agencies for handling domestic violence cases, which would include psychologists, social workers, pedagogues etc. besides legal practitioners. Sixty-eight percent of judges and $48 \%$ of prosecutors supported the forming of a specialized structure for handling domestic violence cases.

Another solution could be the establishment of regular networks of response to domestic violence in all counties of Estonia.The questioning of specialists showed that although domestic violence response networks exist in Estonia, they often operate occasionally, without regularity, there are no agreements or consistent management. This holds especially true regarding violence against adults; cooperation against abuse of children is somewhat more regular and organized. The passivity and modest role of some parties (health care workers, social workers, women's shelters, schoolteachers, psychologists, family counselors etc.) is another major problem.

In the absence of close cooperation between specialists, the parties of domestic violence cases find it difficult to receive planned systemic aid and integrated assistance package. The existing networks do not include all the necessary specialists, whose participation is vital. The network's membership should be comprehensive, it should include the representatives of all institutions/departments which are charged with intervening in domestic violence cases or helping and supporting the parties involved: the police, prosecutors, judges, court social workers, victims' aid, social workers, child welfare workers, support center staff, general practitioners and nurses, gynecologists, mental health specialists, pediatricians, social pedagogues, teachers, housing providers, parole officers, AA representatives etc.

The role of practicing legal specialists (prosecutors, police investigators, lawyers, judges etc.) in this network would include providing legal aid and drafting legislation: consulting, supporting appeals to court, maintaining competence in legislation and court rulings, knowledge of legal mechanisms for improving security (restraining orders etc.), representing parties involved in domestic violence incidents in civil or criminal cases (the Bar Association) etc.

\section{Conclusions}

Domestic violence is widely spread in Estonia. In 2015, $42 \%$ of women and $40 \%$ of men from the age of 15 until the moment of the survey had experienced violence. (Pettai, Proos \& Laidmäe, 2016). Two thirds of women and every fifth man have experienced violence in their own homes. Efficient prevention of and combating domestic violence is a problem, which has largely remained unsolved in Estonia. In our opinion, achieving progress is primarily obstructed by limited cooperation between organizations and institutions encountering domestic violence. The absence of a law on domestic violence could be pointed out as a secondary factor.

The present system for preventing and combating domestic violence in Estonia consists of law enforcement with the police, the prosecutors' offices and courts, the victims' aid institutions, women's shelters, hotlines for children and adults and women's hotline. As for the law enforcement agencies, prosecutors cooperate significantly more actively in domestic violence cases than judges, cooperating quite closely with police investigators, victims' aid workers and judges. On the other hand there is practically no cooperation with general practitioners and other health care specialists, social workers, women's shelters, school pedagogues, psychologists and family counselors.

Judges are significantly less active in cooperation with other specialists regarding domestic violence. There is some level of cooperation with prosecutors and other judges, but they have not developed close contacts with other specialists. Although cooperation networks on domestic violence exist in Estonia, they often operate haphazardly, irregularly, without binding agreements or planned management. This especially applies to violence concerning adults; cooperation concerning violence against children is somewhat more regular and organized. 
The present networks do not cover all necessary specialists, whose participation is vitally important. The passivity and modest role of some parties (health care specialists, social workers, women's shelters, school pedagogues, psychologists and family counselors) poses considerable problems. Efficient cooperation can only occur as a result of mutual interest and common purposeful efforts.

The development of a common system and cooperation is of decisive importance in efficient prevention of and combating domestic violence. A premise for the establishment of this system would be a law on domestic violence, which would determine the role and tasks of key institutions and specialists in combating violence, timely intervening and preventing serious cases. The law on domestic violence would create preconditions for integrated handling of domestic violence cases, establish rules of behavior (legal norms) for achieving effective outcomes, which would be the discovery of domestic violence at as early stage as possible and its prevention, as well as providing the victims and the violent individuals with an integrated packet of aid.

The present practice with the relevant institutions and specialists operating in relative isolation and autonomy, unfortunately cannot offer effective outcomes. The services provided by institutions and specialists help in solving some individual problems of victims or perpetrators and provide temporary solutions, while there is no opportunity for integrated solutions, which would help the parties involved exit the vicious circle of violence and have a fulfilling life free of violence.

\section{References}

Estonian Government (2015) Vägivalla ennetamise strateegia aastateks 2015-2020 [Strategy for preventing violence for 2015-2020]. Tallinn 2015. [Online] Available: https://valitsus.ee/sites/default/files/content-editors/arengukavad/vagivalla_ennetamise_strateegia_20152020_kodulehele.pdf (March 13, 2019)

Kaljulaid, K. (2017) President Kersti Kaljulaid speech at the Republic of Estonia Independence Day celebration in Estonia Concert Hall on February 24, 2017. [Online] Available: https://president.ee/et/ametitegevus/koned/14739-vabariigi-president-iseseisvuspaeeval-estonia-teatri-jakontserdimajas-24-veebruaril-2017/index.html (March 13, 2019)

Narits, R., Kaugia, S., Pettai, I. (2016). The Significance of Recognising Domestic Violance, in Light of Estonian Legal Experts' Opinion and the Prospects for Systematising the Relevant Legislation. Juridica International 24, 128138.

Pettai, I. (2015). Perevägivald Eestis juristi pilgu läbi. Lühikokkuvõte ekspertküsitluste tulemustest [Domestic violence in Estonia - a legal viewpoint. Brief summary of outcomes of expert survey]. Tallinn. [Online] Available: https://www.sm.ee/sites/default/files/contenteditors/eesmargid_ja_tegevused/Norra_toetused/Koduse_ja_soopohise_vagivalla_vahendamise_programm/tul emused-juristide_kusitlus_draft.pdf (March 13, 2019)

Pettai, I., Kase, H. (2014). Perevägivald Eestis tervishoiutöötaja pilgu läbi. Üle-eestilise ekspertküsitluse tulemused [Domestic violence in Estonia - health care workers' viewpoint. Results of nationwide survey of experts]. Eesti Avatud Ühiskonna Instituut. [Online] Available: http://media.voog.com/0000/0035/2397/files/7_\%20Meedikute\%20küsitlus.pdf. (March 13, 2019)

Pettai, I., Kaugia, S., Narits, R. (2015). Perevägivald nõuab jõulisemat juriidilist sekkumist [Domestic Violence: Social Phenomenon that Requires a more Forceful Legal Intervention]. Riigikogu Toimetised, 31, 155-167.

Pettai, I., Narits, R., Kaugia, S. (2015). Perevägivalla juriidilise regulatsiooni hetkeseis ja perspektiiv Eesti õiguspraktikute küsitluse põhjal [State of the legal regulation on domestic violence and perspective from Estonian lawyers]. Juridica, IX, 645-658.

Pettai, I., Proos, I. (2014). Perevägivald Eestis sotsiaaltöötaja pilgu läbi. Üle-eestilise ekspertküsitluse tulemused [Domestic violence in Estonia - social workers' viewpoint. Results of nationwide survey of experts]. Eesti Avatud Ühiskonna Instituut. [Online] Available: http://media.voog.com/0000/0035/2397/files/7_Sotsiaaltöötajate\%20küsitlus.pdf. (March 13, 2019)

Pettai, I., Proos, I. (2015). Lähisuhtevägivald Eestis politsei pilgu läbi. Üle-eestilise ekspertküsitluse tulemused [Intimate partner violence in Estonia - a police viewpoint]. Tallinn. [Online] Available: http://media.voog.com/0000/0035/2397/files/7_Politseitöötajate\%20küsitlus.pdf (March 13, 2019)

Pettai, I., Proos, I. (2015). Perevägivald Eestis juristide pilgu läbi. Üle-eestilise ekspertküsitluse tulemused [Domestic violence in Estonia - a legal viewpoint. Results of nationwide survey of experts]. Eesti Avatud Ühiskonna Instituut. [Online] Available: http://media.voog.com/0000/0035/2397/files/7_Aruanne\%20Juristide\%20küsitlus.pdf. (March 13, 2019) 
Pettai, I., Proos, I., Laidmäe,V.-I. (2016). Pere- ja naistevastane vägivald ja ohvrite tervis Eestis [Domestic violence, violence against women and the victims' health]. Tallinn. Eesti Avatud Ühiskonna Instituut.

Salla, J., Surva. L. (2012). Perevägivallatsejate retsidiivsus. Kriminaalpoliitika analüüs, 8. Justiitsministeerium [Recidivism of domestic violence perpetrators. Analysis of criminal policy 8/2012]. [Online] Available: http://www.kriminaalpoliitika.ee/sites/krimipoliitika/files/elfinder/dokumendid/perevagivallatsejate_retsidiivsu s._justiitsministeerium._2012.pdf (March 13, 2019)

The Ministry of Justice (2016). Kuritegevus Eestis 2015 [Crime in Estonia 2015]. Tallinn, p 34. [Online] Available:

http://www.kriminaalpoliitika.ee/sites/krimipoliitika/files/elfinder/dokumendid/kuritegevus_eestis_2015.pdf (March 13, 2019)

The Ministry of Justice (2017). Kuritegevus Eestis 2016. Kriminaalpoliitika arengusuunad aastani 2018: 2016. aasta täitmise ettekande lisa Riigikogule. 8. märts, 2017 Justiitsministeerium [Crime in Estonia 2016]. Tallinn. [Online] Available:

http://www.just.ee/sites/www.just.ee/files/kriminaalpoliitika_arengusuundade_taitmine_2016_lisa.pdf. (March 13, 2019)

UN Woman (2018) Facts and figures: Ending violence against women. [Online] Available: http://www.unwomen.org/en/what-we-do/ending-violence-against-women/facts-and-figures (March 13, 2019)

\section{Appendix}

Table 1. Cooperation with different specialists

\begin{tabular}{|l|l|l|l|l|l|l|l|l|l|}
\hline & $\begin{array}{l}\text { Average } \\
\text { rating of } \\
\text { cooperation }\end{array}$ & \multicolumn{2}{l}{ Prosecutors } & \multicolumn{2}{l}{ Judges } & \multicolumn{2}{l|}{$\begin{array}{l}\text { Police- } \\
\text { investigators }\end{array}$} & $\begin{array}{l}\text { Lawyers } \\
*\end{array}$ \\
\cline { 2 - 12 } & $\mathbf{2 0 1 7}$ & $\mathbf{2 0 1 4}$ & $\mathbf{2 0 1 7}$ & $\mathbf{2 0 1 4}$ & $\mathbf{2 0 1 7}$ & $\mathbf{2 0 1 4}$ & $\mathbf{2 0 1 7}$ & $\mathbf{2 0 1 4}$ & $\mathbf{2 0 1 7}$ \\
\hline $\begin{array}{l}\text { 1. With prosecutor's } \\
\text { office staff }\end{array}$ & 49 & 56 & 87 & 93 & 25 & 36 & 64 & 66 & 21 \\
\hline $\begin{array}{l}\text { 2. With police } \\
\text { investigators }\end{array}$ & 49 & 49 & 82 & 67 & 15 & 12 & 75 & 75 & 16 \\
\hline $\begin{array}{l}\text { 3. Victim support } \\
\text { workers }\end{array}$ & 41 & 36 & 68 & 55 & 15 & 8 & 68 & 56 & 5 \\
\hline 4. With judges & 26 & 33 & 47 & 69 & 25 & 32 & 21 & 23 & 13 \\
\hline $\begin{array}{l}\text { 5. Women's shelters } \\
\text { staff }\end{array}$ & 20 & 20 & 26 & 21 & 5 & 8 & 36 & 29 & 8 \\
\hline $\begin{array}{l}\text { 6. Local governments' } \\
\text { child welfare workers }\end{array}$ & 21 & 19 & 16 & 14 & 25 & 12 & 30 & 27 & 13 \\
\hline $\begin{array}{l}\text { 7. With local } \\
\text { governments' social } \\
\text { workers }\end{array}$ & 10 & 14 & 11 & 12 & 10 & 8 & 14 & 22 & 5 \\
\hline $\begin{array}{l}\text { 8. With family } \\
\text { counselors and } \\
\text { psychologists }\end{array}$ & 8 & 13 & 16 & 14 & 0 & 12 & 5 & 17 & 8 \\
\hline $\begin{array}{l}\text { 9. With local school } \\
\text { staff }\end{array}$ & 9 & 9 & 8 & 5 & 5 & 4 & 21 & 18 & 3 \\
\hline $\begin{array}{l}\text { 10. With general } \\
\text { practitioners and } \\
\text { specialized physicians }\end{array}$ & 3 & 6 & 8 & 5 & 0 & 4 & 2 & 10 & 0 \\
\hline $\begin{array}{l}\text { 11. With representatives } \\
\text { of women's } \\
\text { organizations }\end{array}$ & 4 & 5 & 5 & 5 & 0 & 8 & 7 & 8 & 3 \\
\hline
\end{tabular}

Source: Estonian Institute for Open Society Research, 2014; Research project of the Estonian Institute for Open Society Research and the University of Tartu Faculty of Law "Domestic violence in Estonia", 2017 * The answers concerning lawyers only apply to 2017. There were not enough respondents in 2014. 